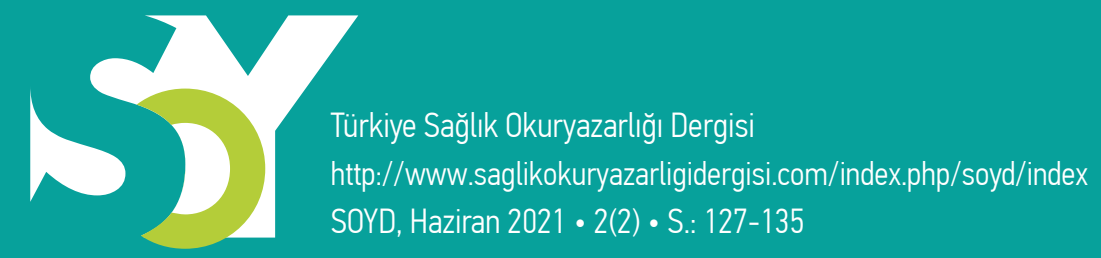

E-ISSN: 2717-7831

Başvuru | 26 Mayıs 2021

Kabul | 29 Haziran 2021

DOI: 10.54247/SOYD.2021.34

\title{
21. Yüzyıl Salgınları
}

\section{1st Century Outbreaks}

\author{
Merve Atik Şahin' \\ 1 Gazi Üniversitesi Tıp Fakültesi Halk Sağı̆ğı Anabilim Dalı
}

Dilek Yapar ${ }^{1}$ iD

\begin{abstract}
Öz
Salgın, bir hastalı̆̆ın, belirli bir bölgede, belirli bir zaman aralığında, beklenenden fazla görülmesi ya da belirli ortak özellikleri nedeniyle kümeleşme göstermesi olarak tanımlanmaktadır. 21. yüzyıl salgın hastalıkları, yeni ve yeniden tanımlanan bulaşıcı hastalıklar, bulaşıcı olmayan kronik dejeneratif hastalıklar ve ruh sağlığı hastalıkları olarak incelenmiştir. Bu hastalıkların alt başlıklarında; diyabet, kalp hastalıkları, kanserler, kronik solunum yolu hastalıkları, Alzheimer, depresyon, anksiyete, internet ve oyun bağımlılı̆ı, yeme bozuklukları, çocuk istismarı, madde bağımlıı̆ı, yeni görülen veya yeniden görülen enfeksiyonlar, AIDS, Sarı Humma, Tifo, Shigella, Meningokok, COVID-19 virüsü, zoonotik İnfluenza virüsleri, Chikungunya virüsü, Kırım Kongo Kanamalı Ateşi virüsü, Zika virüsü ve MERS virüsleri ve diğer bulaşıcı hastalık etkenleri olarak düşünülmüş ve açıklanmıştır. Günümüz hayat şartlarının değişimiyle meydana gelen beslenme ve yaşam tarzı değişiklikleri, globalleşme süreci, sağlığın sosyal belirleyicileri ve toplumların yetersiz sağlık okuryazarlığına sahip olması bulaşıcı ve bulaşıcı olmayan hastalıkların artışının başlıca nedenleri olarak tartışılmıştır. Bu derlemede 21. yüzyılda yaşanılan tüm salgınlara güncel bir yaklaşım sunulması amaçlanmıştır.
\end{abstract}

Anahtar Kelimeler: 21. Yüzyıl Salgınları, Bulaşıcı Hastalıklar, Bulaşıcı Olmayan Hastalıklar, Ruh Sağlığı Hastalıkları, Sağlık Okur Yazarlığı, İnfodemi, Sağlığın Sosyal Belirleyicileri.

\begin{abstract}
An epidemic is defined as the occurrence of a disease in a certain region, in a certain time interval, more than expected or aggregation due to certain common characteristics. 21st century epidemic diseases were examined as new and redefined infectious diseases, noncommunicable chronic degenerative diseases and mental health diseases. In the subtitles of these diseases; diabetes, heart diseases, cancers, chronic respiratory diseases, Alzheimer's, depression, anxiety, internet and game addiction, eating disorders, child abuse, substance addiction, AIDS, Yellow Fever, Typhoid, Shigella, Meningococcus, COVID-19 virus, zoonotic influenza viruses are considered and described as Chikungunya virus, Crimean Congo Hemorrhagic Fever virus, Zika virus and MERS viruses are thought and explained. Dietary and lifestyle changes that occur with the changes of today's living conditions, increasing transportation and communication around the world, social determinants of health and inadequate health literacy are discussed as the main reasons for the increase of communicable and non-communicable diseases. In this review, it is aimed to present an up-to-date approach by mirroring the COVID-19 virus pandemic and other epidemics in the 21 st century.
\end{abstract}

Keywords: 21st Century Outbreaks, Communicable Disease, Noncommunicable Disease, Mental Disoreder, Health Literacy, İnfodemic.

Alıntı Şekli: Atik Şahin M, Yapar D. 21. Yüzyıl Salgııları . SOYD. 2021;2(2):127-135

Sorumlu Yazar:

Merve Atik Şahin, Gazi Üniversitesi Tıp Fakültesi Halk Sağlı̆̆ı Anabilim Dalı

E-mail: drmerveatik@outlook.com 


\section{YÖNTEM}

"Pubmed", "Google Scholar" ve "Researchgate" veri tabanları kullanılarak bu çalışma hazırlanmıştır. Çalışmada kullanılan anahtar kelimeler: "noncommunicable diseases", "communicable diseases", "mental health", "health literacy" ve "COVID-19" olarak seçilmiştir.

\section{GiRiş}

Zaman süreci içinde dünyanın sağlık ile ilgili bilgi, davranış, farkındalık ve tutumları, sosyal hayatları, çevre koşulları, ekonomik imkanları, sağlık alanındaki yeni buluş ve uygulamalar değişim göstermektedir. Bu süreç içinde bazı sorunlar yaygınlaşırken bazılarının önemini gün geçtikçe yitirmesi, toplulukların sık ya da nadir karşılaşılan hastalıklarının değişimine ve yeni sağık sorunlarının oluşumuna yol açmaktadır. Kitleler halinde öldüren bulașıcı hastalıklar; ilaçlar, antibiyotikler, aşılar ve yeni teknolojiler sayesinde kontrol altına alındıktan sonra bulaşıcı olmayan kronik dejeneratif hastalıklar tüm dünyayı etkisi altına almıştır (1). Yine teknolojinin günümüz insan hayatına her alanda girmiş olmasıyla birlikte artan internet ve oyun bağımlı̆̆ı̆, COVID-19 pandemisi ve COVID-19 pandemisine paralel sosyal izolasyon artışına bağı kitlesel ruh sağlı̆ı bozuklukları, son 50 yılda dünya çapında artan prevalansı ile pandemi boyutuna ulaşan obezite gibi pek çok yeni sağlık problemlerinde artış dikkat çekmektedir $(2,3,4)$. 21.yüzyılda yaşanan salgınlar bu derlemede 3 başlık altında toplanmıştır. Bulaşıcı mikrobik hastalıklar, bulaşıcı olmayan kronik hastalıklar, ruh sağıı̆ı hastalıkları. Bu derlemede 21. yüzyıl salgınlarının tümüne panoramik bir bakış sağlanması amaçlanmış ve 21. yüzyıl salgınlarının sağlık okuryazarlığını ile ilişkisine değinilmiştir. İnfodemi, metinflamasyon ve sağlığın sosyal belirleyicileri kavramları açıklanarak yazıma katkı sağlanması amaçlanmıştır.

\section{YÜZYILIN SALGINLARI: BULAŞICI HASTALIKLARI}

Salgın; bir bölgedeki popülasyonda, belirli bir zaman periyodunda, beklenenin üzerinde vaka olması anlamına gelmektedir (5). Daha eski çağlarda toplum sağlığını ciddi derecede tehdit eden mikrobik enfeksiyonlar, 21. yüzyılın başlarından itibaren ilaç endüstrisinin gelişimi ve sağlık bilimindeki gelişmelerle birlikte önemini yitirmiş gibi görünse de, 2019 yılının sonlarına doğru Çin'in Wuhan kentinde başlayan yeni tip COVID-19 virüsünün yol açtığı pandemi, bulaşıcı hastalık etkenlerinin sürekli evrim geçirdiğini ve insan hayatı devam ettiği sürece bulaşıcı enfeksiyonların yol açtığı salgınların da var olmaya devam edeceğini tüm dünyaya hatırlatmıştır (6).
Artan global ulaşım ve ticaret, doğal afetlerden ve savaşlardan kaçan nüfusların kitlesel yer değişimleri, daha iyi hayat standartları için şehir merkezlerinde artan insan nüfusu, 21. yüzyılda salgınların eski çağlara göre çok daha hızlı yayılmasına sebebiyet vermektedir. 21. yüzyılda artık bulaşıcı hastalık kaynaklı salgınların çok daha hızı yayıldığı, daha fazla sayıda insanı etkilediği, seyahati, ticareti, günlük hayatı daha çok etkilediği, daha çok panik, anksiyete, strese neden olduğu ve ekonomiler üzerinde daha yıkıcı bir etkisi olduğu düşünülmektedir (7). Örneğin; 2009 yılında grip virüsü tüm kıtalara 9 haftadan daha kısa sürede yayıımıştır (8).

21.yüzyılın en büyük olaylarından biri elbette ki Coronovirüs pandemisidir; Coronavirüs'ün tüm dünyaya yayılması, yüzyılın en büyük sağlık krizi ve halk sağıkçıların en çok korktuğu senaryonun gerçeğe dönüşmesidir. Daha önceki salgınlardan öğrenilenlerle yola çıkılarak alınan ilk tedbirlerle birlikte dünya çapında devam eden laboratuvar ve klinik araştırmalar ile çözüm arayışları devam etmektedir (9).

30 Ocak 2020'de DSÖ, Coronovirüs pandemisini uluslararası öneme sahip halk sağlığı acil durumu ilan etmiştir. Bu bildiri, DSÖ'nün en yüksek alarm düzeyidir (10). Coronavirüs şu anda dünyada 113 milyon 76 bin 707 onaylanmış vaka, 2 milyon 512 bin 272 ölüme neden olmuştur (11). Türkiye'de 2 milyon 693 bin 164 onaylanmış vaka ve 28 bin 503 ölüm izlenmiştir (12).

Tüm Dünyayı etkisi altına alan COVID-19 virüsü pandemisinde, değişen yaşam koşulları ile birlikte insan davranışları üzerinde önemli bir etkisi olduğu düşünülen yeni bir kavram ortaya çıkmıştır: İnfodemi.

İnfodemi tanımlanabilir her türlü bilginin hızlı yayılımına ek olarak, söylenti ve dedikodu gibi doğru olmayan bilgilerin cep telefonu, sosyal medya, internet ve diğer teknoloji araçlarıyla hızı bir şekilde yayıımasıdır. Yanlış, yanılıı ı ve tutarsız bilgilerin, sözde uzman kişiler tarafından neredeyse anlık olarak yayılması ile halkın salgını benimseme konusundaki isteksizliğinin birleşmesi hem temel müdahaleyi geciktirerek hem de kafa karışıklığı ve paniğe sebebiyet vererek ciddi zararlara neden olduğu düşünülmüştür (13). Çin'in Wuhan kentinde bildirilen COVID-19 salgınından sonra, DSÖ infodemi ile mücadele için EPI-WIN'i (WHO's Information Network for Epidemics) kurmuştur (14).

Insan patojenlerinin en az \%61'inin hayvan kaynaklı olması da önemli bir tehdit teşkil etmektedir (15). Günümüzde büyük şehirlerin yakınına kurulan çiftlikler, ormansızlaşmaya bağı bozulan yaban hayatı, hayvan pazarları ve bu pazarlarda hayvan türlerinin birbirleri arasında olan iletişim, hayvan yetiştiriciliği ve transportunda çalışan insan kaynaklarının bu yüzyıl için büyüyen bir tehdit oluşturduğu düşünülmektedir (16). 
21. yüzyılda yaşam tarzı değişimleri ve yeni tedaviler ile birlikte mikroorganizma dünyasında da değişimler meydana gelmiş ve yeni görülen veya yeniden görülen enfeksiyonlar kavramı hayatlarımızda yerini bulmuştur. İlk kez ya da yeni tanımlanmayan fakat yeni bölgelerde ilk defa görülen ve hızla artan enfeksiyonlara yeni görülen enfeksiyonlar; uzun zaman boyunca görülmemiş veya çok nadir görülmüş olup beklenmeyen bir zamanda tekrar ortaya çıkan enfeksiyonlara yeniden görülen enfeksiyonlar denilmektedir (17). Dünya çapında yeni ve yeniden önem kazanan enfeksiyonların sıklığının giderek arttığı düşünülmektedir. Ebola, Nipah, Hendra, Zika, şiddetli akut solunum yolu sendromu (SARS), Ortadoğu solunum yolu sendromu (MERS), yeni tip COVID-19 virüsü enfeksiyonu, AIDS, tüberküloz, sıtma ve kuş gribi gibi pek çok hastalık bu enfeksiyonlara örnektir. $(18,19)$.

Dünya Sağlık Örgütüne 2011 yılında 179, 2012 yılında 183, 2013 yilında 164, 2014 yilında 197, 2015 yilında 182, 2016 yilında 213, 2017 yılında 189 salgın hastalık bildirilmiştir. 2011 ile 2017 yılları arasında toplam 57 Sarı Humma epidemisi, 95 Chikungunya virüsü epidemisi, 10 Viral Hemorajik Ateş epidemisi, 22 Ebola virüsü epidemisi, 4 Marburg virüsü epidemisi, 49 Kırım-Kongo Kanamalı Ateşi virüsü epidemisi, 14 Rift Vadisi Humması, 308 Kolera Epidemisi, 75 Tifo epidemisi, 113 Shigella epidemisi, 47 Veba epidemisi, 23 Lassa ateşi epidemisi, 91 Batı Nil Ateşi epidemisi, 137 Zika virüsü epidemisi, 137 Meningokok epidemisi, 57 MERS epidemisi, 51 İnfluenza A epidemisi, 10 Monkeypox epidemisi, 2 Nodding Sendromu epidemisi ve 5 Nipah virüsü epidemisi bildirilmiştir. (20).

Bunlara ek olarak kuş gribi ve diğer zoonotik influenzalar (H1N1, H1N5 ve diğerleri), Dang Humması, Veba, SARS, Sıtma, Kabakulak, Kızamıkçık, Tüberküloz, Kızamık, HIV ve MERS; 21. yüzyılda salgınlara neden olan diğer önemli bulaşıcı hastalıklar ve etkenlerdir $(21,22)$.

\section{YÜZYIL SALGINLARI: BULAŞICI OLMAYAN KRONIK HASTALIKLAR}

Bulaşıcı olmayan kronik hastalıklar 21. yüzyılda önde gelen halk sağlığı sorunlarından birisidir ve toplumların ekonomisi, sağı̆ğı ve yaşam kalitesi üzerinde çok ciddi bir yüke neden olmaktadır. Bulaşıcı olmayan hastalıklar $(\mathrm{BOH})$, çok faktörlü karmaşık bir etiyolojik alt yapısı olan, bulaşıcı olmayan, uzun bir latent periyodu olan, sağaltımı mümkün olmayan, kronik hastalıklar için kullanılan bir terimdir (23).

21. yüzyıla damgasını vuran önemli $\mathrm{BOH}$; kanserler, kardiyovasküler hastalıklar, diyabet, kronik solunum yolu hastalıkları, alzheimerdır $(24,25)$.
BulaşıCı olmayan kronik hastalıklar, COVID-19 pandemisinden önce; küresel, bölgesel ve ulusal düzeyde ölüm sebebi sayılan, tüm dünyada 21. yüzyllın en önemli halk sağlığı problemi olarak görülen hastalıklar idi. Bulaşıcı olmayan hastalıklar her yıl 41 milyon kişinin ölümüne sebebiyet vermektedir ve bu sayı tüm dünya çapındaki ölümlerin \%70'idir. Ayrıca her yıl 30-69 yaş arası 15 milyon kişi bulaşıcı olmayan hastalıklardan hayatını kaybetmektedir ve bu erken ölümlerin $\% 80$ 'den fazlası, düşük ve orta gelirli ülkelerde gerçekleşmektedir (26). Türkiye'deki tüm ölümlerin \% 87,5 'i bulaşıcl olmayan hastalıklardan kaynaklanmaktadır (27).

Batı yaşam tarzının dünya genelinde yaygınlaşması ile birlikte değişen hayat tarzı, alkol ve tütün kullanımının artması, fiziksel aktivitenin azalması, hava ve çevre kirliliğindeki artış, diyetteki tuz oranının artması, beslenmede taze sebze ve meyve alımının azalması ve artan günlük kalori alımı bulaşıcı olmayan kronik dejeneratif hastalıkların tüm dünyada artmasına neden olmuştur (28). Geçmişten günümüze diyetle ilgili alışkanlıklarımızdaki anahtar değişikliklerin; vücudumuzdaki reaktif oksijen türlerini ve oksidatif stresin üretimini arttırdığı, hiperinsülineminin ve insülin direncinin gelişmesine neden olduğu, meta-inflamasyona (ya da metinflamasyon) yol açtığı, sempatik sinir sisteminin ve renin-anjiyotensin sisteminin anormal aktivasyonuna neden olduğu ve tüm bu sebeplerin $\mathrm{BOH}$ gelişiminde kilit bir role sahip olduğu düşünülmektedir $(29,30)$. Ek olarak, diyetle ilgili değişikliklerin fetus gelişimini dahi etkilediği ve bu fetusların yetişkin hayatında obezite, insülin direnci, tip 2 diyabet ve kardiyovasküler hastalıklar açısından daha yüksek risk taşıdığı ileri sürülmüştür (31).

Kronik dejeneratif hastalıkların patogenezinde önemli bir yere sahip olduğu düşünülen, kronik ve yavaş ilerleyen, düşük seviyeli inflamasyon için metinflamasyon terimi kullanılmıştır. Metinflamasyonun kronik hastalıklar için önemi yeni keşfedilmekle beraber, metabolik sendromun ve aşırı miktarlarda yağı, kalorili, fruktozlu beslenmenin metinflamasyonu tetiklediği ve tetiklenen metinflamasyonun, kronik inflamasyona, hedef organ hasarına, bağırsak florasının değişimine ve vücut epigenetiğinin değişimine neden olarak BOH'u tetiklediği yapılan araştırmalarda gösterilmiştir (32).

$\mathrm{BOH}$ etiyolojisinde sağlığın sosyal belirleyicilerinin de önemli bir rolü olduğu düşünülmektedir ve DSÖ'ye göre, sağlığın sosyal belirleyicileri "insanların doğduğu, büyüdüğü, çalışıı̆ı, yaşadığı ve yaşlandığı koşullar ve günlük yaşamın koşullarını şekillendiren güçler ve sistemler bütünüdür." Ulusal Araştırma Konseyi ve Tıp Enstitüsüne göre, sağlığı belirleyen en önemli sosyal faktörler; gelir, 
eğitim, Irk ve etnik gruplar, mesleki özellikler ve bu faktörlerin getirdiği sosyal eşitsizliktir ve bu değişkenlerin başka bir deyişle çevresel faktörlerin toplumsal sağlık üzerinde doğrudan etkileri bulunmaktadır (33). Bazı çalışmalarda $\mathrm{BOH}$ için "bulaşıcı olmayan" yerine "sosyal olarak bulaşan" terimini önerilmiştir (34).

Kardiyovasküler hastalıklar (KVH) grubunda serebrovasküler hastalıklar, koroner kalp hastalığı, romatizmal kalp hastalığı, konjenital kalp hastalığı, periferik arter hastalı̆̆ı, pulmoner emboli ve derin ven trombozu bulunur $(35,36)$. KVH'lar pandemiden önce dünya çapında en sık görülen ölüm nedeni olarak düşünülmekte idi. DSÖ 2016 yllında dünya genelindeki ölümlerin \%31'ine tekabül eden 17,9 milyon insan ölümünün $\mathrm{KVH}$ sebebi ile olduğunu tahmin etmektedir ve 2015 yllında bulaşıcı olmayan hastalıklara bağlı 17 milyon erken ölümün (70 yaş altı), \%82'sinin düşük ve orta gelirli ülkelerde gerçekleştiği ve bunların \%37'sinin KVH'dan kaynaklandığı tespit edilmiştir (37). Hipertansiyon, dünya çapında erken ölümün başlıca nedenlerinden olup, DSÖ'ye göre dünyada 1,13 milyar insanın hipertansiyon hastası olduğu tespit edilmiştir. 2015 yııında 4 erkekten 1'inde ve 5 kadından 1 'inde hipertansiyon olduğu düşünülmüştür (38). En sık ritim bozukluğu sebebi olan atriyal fibrilasyon (AF) dünya genelinde sessiz bir pandemiye neden olmaktadır. Küresel Hastalık Yükü raporuna göre dünyada 33,5 milyon kişide AF bulunmakta ve bu sayıya her yıl beş milyon yeni AF vakası eklendiği düşünülmektedir (39).

Global obezite prevalansının geçtiğimiz 30 yılda dramatik olarak yükseldiği görülmüştür. Dünyada 2015 yılında toplam 1,9 milyar yetişkinin aşırı kilolu ve 609 milyon yetişkinin ise obez olduğu tahmin edilmektedir ve bu sayı dünya nüfusunun yaklaşık \%39'unu temsil etmektedir (40). Obezite sadece yetişkinlerde değil çocuklarda da görülen önemli bir sağlık sorunudur ve çocuklarda son 14 yılda tüm obezite kategorilerinde artış izlenmiştir (41).

Non-alkolik yağlı karaciğer hastalığı (NAYKH), obezite ve metabolik sendromun devamı niteliğindedir ve şu anda dünyada en çok görülen karaciğer hastalığıdır. Obezite salgınının yayılması ile artan NAYKH günümüzde karaciğer nakli için temel endikasyonlardan biri haline gelmiştir (42).

Diyabet hastalığı olan kişi sayısı dünya genelinde 1980 yilında 108 milyon iken, 2014'de bu sayı 422 milyona ulaşmıştır ve dünyada 18 yaşın üzerinde diyabet prevalansı 1980 ylında \%4,7 iken, 2014'de bu prevalans \%8,5'e yükselmiştir. Diyabete bağlı ölümlerin neredeyse yarısı 70 yaşından önce meydana gelmekte ve 20002016 yılları arasında dünya çapında diyabete bağı erken ölümlerde \%5 artış olmuştur (43). Dünya'da 20 ile 79 yaş arasında 2019 yılında yaklaşık 463 milyon insanın diyabet hastası olduğu düşünülmüştür. 2045 yılında bu sayının 700 milyonu aşacağı öngörülmektedir (44).

Dünya nüfusu yaşlandıkça, küresel çapta bir Alzheimer salgınıyla karşı karşıya kalacağımız düşünülmektedir. 2006'da dünya çapında 26,6 milyon insanın Alzheimer hastası olduğu tahmin edilmektedir. 2050'ye kadar Alzheimer prevalansının dört kat artacağı, dünya genelinde 85 kişiden 1'inin bu hastalık ile yaşıyor olacağı ve bu vakaların yaklaşık \%43'ünün yüksek düzeyde bakıma intiyaç duyacağı öngörülmektedir (45).

Kanser insidansı ve ölüm oranı dünya çapında hızla artmaktadır ve dünya genelinde ölümlerin en sık ikinci sebebi haline gelmiştir. 2018 yilında tüm dünyada 18,1 milyon yeni vaka ve 9,6 milyon kansere bağlı ölüm tahmin edilmekte olup küresel olarak yaklaşık altı ölümden biri kanser kaynaklıdır. Kanserin ekonomik etkisinin önemi de gün geçtikçe artmaktadır. 2010 yılında kanserin, dünya genelinde toplam yıllık maliyetinin yaklaşık 1,16 trilyon ABD doları olduğu tahmin edilmektedir $(46,47)$.

Bulaşıcı olmayan hastalıklara ilişkin 2008-2013 Dünya Sağlık Örgütü eylem planında dört öncelikten biri olarak kronik solunum yolu hastalıkları bulunmaktadır. Çoğunluğu gelişmekte olan ülkelerde olmak üzere bir milyar insan kronik solunum yolu hastalıklarına sahiptir (48). 21. yüzyılda $K O A H$, özellikle sigara kullanımının artmasına bağlı olarak küresel bir halk sağlığı krizi haline gelmiştir (49). Global Burden of Disease, 2016 yilında tüm dünyada 251 milyon $\mathrm{KOAH}$ vakası olduğunu bildirmiştir. 2015 yllında dünyada 3,17 milyon insanın ölümünün KOAH'a bağlı olduğu tahmin edilmektedir ve bu sayı tüm dünyadaki ölümlerin \%5'idir (50).

\section{YÜZYIL SALGINLARI: RUH SAĞLIĞI HASTALIKLARI}

Dünya Sağlık Örgütü anayasasında sağlık şöyle tanımlanmıştır: "Sağlık sadece hastalık ve sakatığın olmayışı değil; bedence, ruhça ve sosyal yönden tam iyilik halidir." (51). 21. yüzyılda ruh sağlığı dahil olmak üzere, sağlık alanında yapılan iyileştirmeler ile birlikte, büyük kazanımlar elde edilmiş olmasına rağmen, nöropsikiyatrik hastalıklar dünya çapında engelliliğin önde gelen nedenlerindendir ve hastalıkla geçirilen zamanın \%37'sini oluşturmaktadır (52). Gözlemciler son 30 yılda ruh sağlığı hastalıklarında endişe verici bir artış olduğuna dikkat çekmektedir (53).

DSÖ, Avrupa'da engelli olma durumunun en sık üçüncü sebebi olarak (kardiyovasküler hastalıklar ve kanserlerden sonra) ruh sağlığı hastalıklarını söylemektedir (54). 
Yine DSÖ verilerine göre Avrupa Bölgesinde ruh sağlığı hastalıklarının tahmini prevalansı 2015 yılında 137 milyon yani toplam nüfusun \%15'idir (55).

21. yüzyılda özellikle internet ve oyun bağımlılığı, anksiyete bozuklukları, depresyon, cinsel istismar, madde bağımlılı̆ı ve aşıı yeme bozukluğu dikkat çekmektedir. Ayrıca COVID-19 pandemisinde de sosyal izolasyona bağlı ruh sağlığı bozukluklarının arttığı düşünülmektedir.

Nöropsikiyatrik bozukluklar, Avrupa Bölgesinde hastalık yükünün \%19,5'ini ve Avrupa Birliği ülkelerinde \%26'sını oluşturmaktadır. Her yıl, Avrupa nüfusunun \%25'inde depresyon ve anksiyete görülmektedir (56).

Depresyon, yaygın bir zihinsel bozukluktur. Dünyada 264 milyondan fazla insanı etkilemektedir ve intihar sebebi olabilmektedir (57). Her yıl 800.000'e yakın kişi intihar nedeniyle ölmektedir. İntihar 15-29 yaş aralığında görülen en sık üçüncü ölüm nedenidir (58). DSÖ anksiyete bozukluklarıın dünya çapında en yaygın zihinsel bozukluklar olduğunu bildirmiştir (59).

Madde kullanım bozuklukları salgını ve aşırı dozda uyuşturucu ölümleri, Amerika Birleşik Devletleri'nde büyüyen bir halk sağlı̆ı krizidir ve her gün 174 kişinin aşırı dozda uyuşturucudan öldüğü gösterilmiştir (60). Esrar, gençler arasında en yaygın kullanılan psikoaktif uyuşturucudur ve 2018 yılında yapılan bir çalışmada 15-16 yaş popülasyonun yaklaşık \% 4,7 'sinin en az bir kez esrar kullanmış olduğu gösterilmiştir (61).

2006 Çocuklara Yönelik Şiddet Dünya Raporuna göre, 2002 yllında, 1,2 milyon insan ticareti ile istismar edilen çocuk ve 1,8 milyon fuhuş veya pornografi yoluyla istismar edilen çocuk dahil olmak üzere, dünya çapında yaklaşık 150 milyon kız ve 73 milyon erkek çocuğun cinsel istismara maruz kaldığı tahmin edilmektedir (62).

İnternet bağımllı̆̆ı genel popülasyonda en yüksek yaygınlıkla \%10,9 prevalans ile Orta Doğu'da ve en düşük \%2,6 prevalans ile Kuzey ve Batı Avrupa`da görüldüğü gösterilmiş ve internet bağımlılı̆ı olan popülasyonun $\% 63,8$ 'inin aynı zamanda oyun bağımlılığı kriterlerini de karşıladığını gösterilmiştir (63).

2016 yılında, dünya çapında 10-19 yaşları arasındaki her altı ergenden birinin aşırı kilolu olduğu tespit edilmiştir. Aşırı yeme bozukluğunun toplum prevalansı \%2-5 olup, kilo kontrol tedavisi alan bireylerde bu prevalans \%30'dur (64).

Belirsizlik veya bilinmeyenle karşı karşıya kaldığımız zaman korku, endişe, stres normal tepkilerimizdir. COVID-19 pandemisinde de kişilerin virüse yakalanma korkusu yaşadığı ve buna ek olarak karantina hayatının getirdiği evden çalışma, geçici işsizlik, çocukların evde eğitim görmesi ve aile üyeleri, arkadaşlar ve meslektaşlarla fiziksel temas eksikliği ve sosyal izolasyon nedeniyle ruh sağlığı bozukluklarının görülme sıkığını arttığı yönünde yapılan çalışmalar artmıştır (65).

\section{YÜZYILSALGINLARI: SAĞLIK OKURYAZARLIĞI íLişKisi}

20. yüzyılın ikinci yarısına kadar olan dönemde bulaşıcı hastalıklar ve bu hastalıkların önlenmesi odak noktası iken 1950'lerden itibaren kronik dejeneratif hastalıklar başta olmak üzere bazı hastalıklar dünya çapında artarak toplumların sağlığı tehdit etmektedir.

Dünya genelinde sıklığı artan hastalıklar hakkında, önemlerinin de artmış olmasına paralel, yapılan epidemiyolojik çalışmalar, klinik araştırmalar ve korunma yaklaşımlarında yükselen bir trend izlenmektedir (66). Toplumların sağlı̆ı̆ı iyileştirmek, geliştirmek ve sağlıkı yaşlanma kavramını yaşatabilmek adına koruyucu sağlık hizmetlerinde sağlı̆ı̆ sosyal belirleyicilerinden biri olarak görülebilen sağlık okuryazarı̆̆ı kavramı son yıllarda büyük ilgi görmektedir (67).

Sağlık okuryazarlığı terimi, giderek değişen toplum yapılanmasında, farklılaşan taleplere yanıt olarak, yıllar içinde çeşitli şekillerde tanımlanmış ve ölçülmüştür (68). Dünya Sağlık Örgütü sağlık okuryazarlığını, "Kişisel ve toplum sağlı̆̆ını iyileştirmek adına harekete geçmek için, sağlık sorunları ve bu sorunlardan korunma yöntemleri ile ilgili bilgi, kişisel beceri ve güven seviyesine ulaşılması sağlık okur yazarlığı anlamına gelir. Bu çerçevede sağlık okuryazarlığı broşür okuyabilmekten ve randevu alabilmekten çok daha fazlasıdır. İnsanların sağlık bilgilerine erişimini kolaylaştırmak ve tüm bunları etkili bir şekilde kullanmalarını sağlamak, sağlık okuryazarlığını güçlendirmek için kritik bir öneme sahiptir. " diyerek tanımlamaktadır (69).

Sağlık okuryazarlığının dünyada ve ülkemizde yetersiz seviyede olduğu düşünülmektedir. Amerika'da Ulusal Yetişkin Sağlık Okuryazarlığı Değerlendirmesine göre yetişkin nüfusun \%53'ünün sağlık okuryazarlığının orta düzeyde, \%36'sının yetersiz, \%22'sinin temel düzeyde olduğu belirlenmiştir (70). Amerika'daki yetişkin nüfusun yaklaşık yarısının sağlık bilgilerine göre yaşam tarzını düzenleyemediği düşünülmektedir (71). Dünya Sağlık Örgütünün 2009 ile 2012 yılları arasında Avrupa Birliği ülkelerinde yaptığı Avrupa Sağlık Okuryazarlığı projesinde yetersiz ve sorunlu sağlık okuryazarliğı oranları Avusturya'da $\% 56,4$, Bulgaristan'da \%62,1, Almanya'da \%46,3, Yunanistan'da \%44,8, İrlanda'da \%40, Hollanda'da $\% 31,7$, Polonya'da \%44,6 ve İspanya'da $\% 47,6$ olduğu belirtilmektedir (72). 
Türkiye'de, Türkiye Sağlık Okuryazarlığı (TSOY-32) ölçeği kullanılarak 2017 ylında yapılan bir araştırmada, toplumunun \%68,9'unun sınırlı veya yetersiz sağlık okuryazarlı̆ı kategorisinde yer aldığı izlenmiştir (73).

BOH kapsamında, sağlık okuryazarlığı eksikliği, halk sağlığı için sessiz ama ciddi bir tehdit oluşturarak daha fazla ölüme, hastalıkların oluşmasına, sağlıksız bir nüfusla ilişkili olarak artan ekonomik kayıplara, hastalıklarla ilgili komplikasyonların artmasına, uzun süreli hastalıkları kendi kendine yönetme becerisinin zayıflamasına ve sağlık sistemlerinin aşıı ve efektif olmayan kullanımına neden olduğu düşünülmektedir (74).

Kronik rahatsızıkları olan bireyler ilk tanı aldıklarında, hastalıkları ile ilgili sağık okuryazarlıkları düzeyleri yetersiz olsa da zaman içinde hastalıklarını tanıyıp, hayatlarııı buna göre düzenlemeye yatkınlık gösterdikleri düşünülmektedir. Ancak toplumlar COVID-19 pandemisinde yeni ve hizla gelişen, tüm dünyayı etkisi altına alan, henüz tam olarak çözülememiş sağlık problemlerini barındıran, tedavisi bulunamamış bir halk sağlığı acil durumu ile karşıllaşmışlar ve böylece 21.yüzyılda yaşanan bulaşıcı hastalık krizinin ortasında, sağlık okuryazarlığının toplumların en büyük intiyaçlarından biri haline geldiği düşünülmektedir (75).

Coronavirüs pandemisi ile birlikte sağlık okuryazarlığının iki çarpıcı özelliğinin ön plana çıktığı düşünülmektedir. Sağlık okuryazarlığının bulaşıcı olmayan kronik dejeneratif hastalıkların önlenmesinde olduğu kadar bulaşıcı hastalıkların önlenmesinde de büyük bir yere sahip olduğu görülmüştür. Bir diğer nokta bulaşıcı hastalık kaynaklı salgınlardan korunmada kitlesel ve küresel anlamda alınan önlemler kadar, bireysel sağlık okuryazarlığı ve buna paralel alınan bireysel önlemlerin kilit rolü üstlendiği fark edilmiştir (76). Çağdaș sağlık okuryazarlığının getirdiği bilgiler temel alınarak, kolektivist toplum yaklaşımı ile kişinin kendi bireysel özgürlüğünü kısıtlamasını teșvik etmek, halk sağlığı acil durumunda alınması gereken önlemlerden biri olarak düşünülmektedir (77).

Ruh sağlığı hastalıkları ve ruh sağlığı okuryazarlığı hakkında toplumların yeterli seviyede olmadıkları düşünülmektedir. Bu durumun ruh sağlığı hastalıklarından korunma yöntemleri, tanınması, yardım arama seçenekleri, mevcut tedaviler hakkında bilgilendirme ve akıl sağlığı sorunlarından etkilenen bireyleri destekleme yöntemleri perspektifinde insanlarda eksik veya hatalı bir tutuma neden olduğu düşünülmektedir (78).

Düşük sosyoekonomik özelliklere sahip toplumlarda, kırsal alanlarda yaşayan halkta, göçmenler ve mültecilerde, yaşı nüfusta ve düşük eğitim seviyelerinde, toplumun geneline oranla, sağlık okuryazarlığı düzeylerinde belirgin bir azalma olduğu görülmüştür (79). Eğitim, teknoloji ve iletişim sistemlerindeki tüm gelişmelere rağmen çağdaş sağılık okuryazarlığı perspektifinde davranış değişikliklerinde önemli ve sürdürülebilir sonuçlar elde edilemediği ve toplumdaki sosyal ve ekonomik gruplar arasındaki sağık eşitsizliğindeki farkın kapatılamadığı düşünülmektedir (80).

Toplumların sağlık okuryazarlığını arttırmak için multidisipliner yaklaşımlar önerilmektedir. Devlet, yayın organları, sivil toplum kuruluşları, sosyal medya, toplumsal liderler, halk sağlığı uzmanları, klinik araştırmacılar ve akademisyenlerin sektörler arası iş birliği çerçevesinde yaklaşılarak sağlık okuryazarığının geliştirilebileceği düşünülmektedir (81). Eğitim düzeyi düşük olanların desteklenmesi, amaca yönelik politikalar belirlenmesi, yönetimsel düzenlemeler yapılması ve uygulanması, sağlık eşitsizliğinin azaltılması, doğru beslenme eğitimleri verilmesi, cinsel sağlık eğitimlerinin yaygınlaştıııması, yeni teknolojilerin bu amaç doğrultusunda kullanması ve sağlığın sosyal, ekonomik ve çevresel belirleyicilerine daha fazla odaklanılarak toplumların sağlık okuryazarlığı kavramına katkı sağlanabileceği düşünülmektedir (82).

\section{SONUÇ}

Insanlar, hayvanlar, bitkiler ve bunların ortak çevreleri arasındaki ilişkiyi tanımlayarak ve optimal sağlık sonuçlarına ulaşmak amacıyla yerel, bölgesel, ulusal ve küresel anlamda, işbirlikçi, çok sektörlü ve disiplinler arası bir yaklaşım ile tüm yüzyıl olaylarını ele almamız gerekmektedir. 21. yüzyılda bulaşıcı hastalık etkenleri hem hayvanlarda hem insanlarda yeni veya yeniden tanımlanan zoonotik enfeksiyonların salgınlarına neden olmuştur. 21. yüzyıla damgasını vuran bulaşıcı olmayan başka bir deyişle sosyal olarak bulaşan kronik dejeneratif hastalıklar, toplum sağlı̆ını ciddi anlamda tehdit etmektedir. 21. Yüzyılda ruh sağıı̆ı hastalıklarının da artığı düşünülmekte olup özellikle COVID-19 virüsünün sebep olduğu korku, endişe, yas, işsizlik, gelir kaybı ve sosyal izolasyona bağlı gelişen yalnızığın küresel çapta ruh sağlığı sorunlarında artışa veya var olan ruh sağlığı hastalıklarının şiddetlenmesine yol açtığı tahmin edilmektedir. 21. Yüzyılda salgınlara neden olan hastalıkların etiyolojilerinin merkezinde, dünya genelinde değişen yaşam tarzının, sağlık okuryazarlığının yetersiz ve sorunlu düzeyde olmasının ve sağlığın sosyal belirleyicilerinin olduğu düşünülmektedir. Başarıı halk sağı̆̆ı müdahaleleri gerçekleştirebilmek için tıp, veterinerlik ve çevre sağlı̆ı̆ı uzmanları başta olmak üzere tüm sektörler arasında uyum ve iş birliği sağlanarak toplumsal sağlık için en iyi sonuçların elde edebileceği umut edilmektedir. 


\section{KAYNAKLAR / REFERENCES}

1. Tezcan, S. (2017). Temel Epidemiyoloji. Ankara: Hipokrat Yayınevi.

2. Tam, P., \& Walter, G. (2013). Problematic internet use in childhood and youth: evolution of a 21st century affliction. Australasian Psychiatry, 21(6), 533-536. https://doi. org/10.1177/1039856213509911

3. Nicole Minielly, Chris Feehan, Alissa Wong, Judy Illes, Neuroethical and Societal Challenges of 21st Century Epidemics, Trends in Neurosciences, Volume 43, Issue 12, 2020, Pages 960964, ISSN 0166-2236.

4. Abelson, Philip, and Donald Kennedy. "The obesity epidemic." Science, vol. 304, no. 5676, 2004, p. 1413.

5. Centers For Disease Control And Prevention, Principles of Epidemiology in Public Health Practice, Third Edition An Introduction to Applied Epidemiology and Biostatistics. Lesson 1: Introduction to Epidemiology, Section 11: Epidemic Disease Occurrence. Erişim Adresi: https://www.cdc.gov/csels/dsepd/ ss1978/lesson1/section11.html (16.03.2021)

6. WOIrd Helath Organisations, WHO Director-General's opening remarks at the media briefing on COVID-19- 11 March 2020. Erişim Adresi: https://www.who.int/director-general/speeches/ detail/who-director-general-s-opening-remarks-at-the-mediabriefing-on-covid-19---11-march-2020 (20.02.2020)

7. Türkiye Bilimler Akademisi, Küresel Salgının Anatomisi Insan ve Toplumun Geleceği. (Ankara, 2020) Erişim Adresi: http://www. tuba.gov.tr/files/images/2020/anatomi/K\%C3\%BCresel\%20 Salg \% C 4 \% B 1n \% C 4 \% B 1n \% 20 Anatomisi \% $20 \% 20$ \%C4\%BOnsan\%20ve\%20Toplumun\%20Gelece\%C4\%9Fi.pdf

8. World Health Organisation, Pandemic H1N1 2009. Erişim Adresi: https://www.who.int/global_health_histories/seminars/ presentation43b.pdf?ua $=1$ (16.03.2021)

9. World Health Organisations, A year without precedent: WHO's COVID-19 response. (23.11.2020) Erişim Adresi: https://www. who.int/news-room/spotlight/a-year-without-precedent-who-scovid-19-response (27.02.2021)

10. World Health Organisations, Timeline: WHO's COVID-19 response. Erişim Adresi: https://www.who.int/emergencies/diseases/novelcoronavirus-2019/interactive-timeline (16.03.2021)

11. World Health Organisations, Coronavirus disease (COVID-19) pandemic. Erişim Adresi: https://www.who.int/emergencies/ diseases/novel-coronavirus-2019 (27.02.2021)

12. T.C. Sağıık Bakanlığı, Covid-19 Bilgilendirme Sayfası. Erişim Adresi: https://covid19.saglik.gov.tr/ (27.02.2021)

13. World Health Organisation, Managing the COVID-19 infodemic: Promoting healthy behaviours and mitigating the harm from misinformation and disinformation. Erişim Adresi: https:// www.who.int/news/item/23-09-2020-managing-the-covid-19infodemic-promoting-healthy-behaviours-and-mitigating-theharm-from-misinformation-and-disinformation (16.03.2021)

14. World Health Organisation. About EPI-WIN. Erişim Adresi: https://www.who.int/teams/risk-communication/about-epi-win (22.02.2021)

15. World Health Organisation, Neglected tropical diseases. Erişim Adresi: https://www.who.int/neglected_diseases/diseases/ zoonoses/en/ (16.03.2021)

16. World Health Organisation, Zoonoses. Erişim Adresi: https://www. who.int/news-room/fact-sheets/detail/zoonoses (16.03.2021)

17. Güler, Ç. ve Akın, L. (2015). Halk Sağığı Temel Bilgiler 3. Ankara:Hacettepe Üniversitesi Yayınları
18. Morens, D., Folkers, G. \& Fauci, A. The challenge of emerging and re-emerging infectious diseases. Nature 430, 242-249 (2004). https://doi.org/10.1038/nature02759

19. Sarzhanova, Shakhnoza \& Bozdayı, Gülendam. (2020). Emerging and Re-emerging Viruses. Türk Mikrobiyoloji Cemiyeti Dergisi. 10.5222/TMCD.2020.117.

20. World Health Organisation, Managing epidemics. (2018). Erişim Adresi: https://www.who.int/emergencies/diseases/managingepidemics-interactive.pdf

21. Bloom, D. E., \& Cadarette, D. (2019). Infectious Disease Threats in the Twenty-First Century: Strengthening the Global Response. Frontiers in immunology, 10, 549. https://doi.org/10.3389/ fimmu.2019.00549

22. White, S. J., Boldt, K. L., Holditch, S. J., Poland, G. A., \& Jacobson, R. M. (2012). Measles, mumps, and rubella. Clinical obstetrics and gynecology, 55(2), 550-559. https://doi. org/10.1097/GRF.0b013e31824df256

23. Dünya Sağlık Örgütü, Türkiye Hanehalkı Sağlık Araştırması Bulaşıcı Olmayan Hastalıkların Risk Faktörleri. (2017). Erişim Adresi: https://www.who.int/ncds/surveillance/steps/WHO_ Turkey_Risk_Factors_A4_TR_19.06.2018.pdf

24. World Health Organisation. Total NCD Mortality. Erişim Adresi: https://www.who.int/data/gho/data/themes/topics/indicatorgroups/indicator-group-details/GHO/total-ncd-mortality (23.03.2021)

25. Pistollato, F., Ohayon, E. L., Lam, A., Langley, G. R., Novak, T. J., Pamies, D., Perry, G., Trushina, E., Williams, R. S., Roher, A. E., Hartung, T., Harnad, S., Barnard, N., Morris, M. C., Lai, M. C., Merkley, R., \& Chandrasekera, P. C. (2016). Alzheimer disease research in the 21st century: past and current failures, new perspectives and funding priorities. Oncotarget, 7(26), 3899939016. https://doi.org/10.18632/oncotarget.9175

26. World Health Organisation. Noncommunicable diseases. Erişim Adresi: https://www.who.int/news-room/fact-sheets/detail/ noncommunicable-diseases\#: :text=Noncommunicable $\% 20$ diseases $\% 20$ (NCDs)\%20kill\%2041,71\%25\%20of\%20all\%20 deaths $\% 20$ globally.\&text $=$ Tobacco $\% 20$ use $\% 2 \mathrm{C} \% 20 \mathrm{ph}-$ ysical\%20inactivity $\% 2 \mathrm{C} \% 20$ the of $\% 20$ dying $\% 20$ from $\% 20$ a\%20NCD. (16.03.2021)

27. Hacettepe Üniversitesi Tıp Fakültesi Halk Sağlığı Anabilim Dalı, Türkiye'de Öne Çıkan Bulaşıcı Olmayan Hastalıklar Risk Faktörleri ve Önleme Programları. (2019/2020) Erişim Adresi: http://www. halksagligi.hacettepe.edu.tr/duyurular/halkayonelik/boh2019.pdf

28. World Health Organisation, BulaşıCı Olmayan Hastalıkların Önlenmesine ve Kontrolüne Iliş̧kin Küresel Eylem Planı 20132020. (2013) Erişim Adresi: https://sbu.saglik.gov.tr/Ekutuphane/ kitaplar/bula\%C5\%9F\%C4\%B1c\%C4\%B1\%20olmayan\%20 hastal\%C4\%B1klar.pdf

29. Kopp W. How Western Diet And Lifestyle Drive The Pandemic Of Obesity And Civilization Diseases. Diabetes Metab Syndr Obes. 2019 Oct 24;12:2221-2236. doi: 10.2147/DMSO.S216791. PMID: 31695465; PMCID: PMC6817492.

30. Haim Shapiro, Aviv Lutaty, Amiram Ariel, "Macrophages, MetaInflammation, and Immuno-Metabolism", The Scientific World Journal, vol. 11, Article ID 397971, 21 pages, 2011. https://doi. org/10.1100/2011/397971

31. Mclntyre, H. D., Kapur, A., Divakar, H., \& Hod, M. (2020) Gestational Diabetes Mellitus-Innovative Approach to Prediction, Diagnosis, Management, and Prevention of Future NCD-Mother and Offspring. Frontiers in endocrinology, 11, 614533. https:// doi.org/10.3389/fendo.2020.614533 
32. Li C, Xu MM, Wang K, Adler AJ, Vella AT, Zhou B. Macrophage polarization and meta-inflammation. Transl Res. 2018 Jan;191:2944. doi: 10.1016/j.trsl.2017.10.004. Epub 2017 Nov 3. PMID: 29154757; PMCID: PMC5776711.

33. Cockerham, W. C., Hamby, B. W., \& Oates, G. R. (2017). The Social Determinants of Chronic Disease. American journal of preventive medicine, 52(1S1), S5-S12. https://doi.org/10.1016/j. amepre.2016.09.010

34. Allen LN, Feigl AB. Reframing non-communicable diseases as socially transmitted conditions. Lancet Glob Health. 2017 Jul;5(7):e644-e646. doi: 10.1016/S2214-109X(17)30200-0. PMID: 28619214.

35. World Health Organisation. Cardiovascular Diseases. Erişim Adresi: $\quad$ https://www.who.int/health-topics/cardiovasculardiseases\#tab=tab_1 (16.03.2021)

36. Saquib, N., Zaghloul, M.S., Mazrou, A. et al. Cardiovascular disease research in Saudi Arabia: a bibliometric analysis. Scientometrics 112, 111-140 (2017). https://doi.org/10.1007/s11192-017-2393-z

37. World Health Organisation. Cardiovascular diseases (CVDs). Erişim Adresi: https://www.who.int/news-room/fact-sheets/detail/ cardiovascular-diseases-(cvds) (22.02.2021)

38. World Health Organisation. Hypertension. Erişim Adresi: https:// www.who.int/news-room/fact-sheets/detail/hypertension (22.02.2021)

39. Dilaveris, P. E., \& Kennedy, H. L. (2017). Silent atrial fibrillation: epidemiology, diagnosis, and clinical impact. Clinical cardiology, 40(6), 413-418. https://doi.org/10.1002/clc.22667

40. Chooi, Yu \& Ding, Cherlyn \& Magkos, Faidon. (2018). The Epidemiology of Obesity. Metabolism. 92. 10.1016/j. metabol.2018.09.005.

41. Skinner AC, Skelton JA. Prevalence and Trends in Obesity and Severe Obesity Among Children in the United States, 1999-2012. JAMA Pediatr. 2014;168(6):561-566. doi:10.1001/ jamapediatrics.2014.21

42. Soret, P. A., Magusto, J., Housset, C., \& Gautheron, J. (2020). In Vitro and In Vivo Models of Non-Alcoholic Fatty Liver Disease: A Critical Appraisal. Journal of clinical medicine, 10(1), 36. https:// doi.org/10.3390/jcm10010036

43. World Health Organisation. Diabetes. Erişim Adresi: https://www. who.int/news-room/fact-sheets/detail/diabetes (22.02.2021)

44. International Diabetes Federation, Diabetes facts \& figures. Erişim Adresi: https://www.idf.org/aboutdiabetes/what-is-diabetes/factsfigures.html (02.03.2021)

45. Brookmeyer, R., Johnson, E., Ziegler-Graham, K. and Arrighi, H.M. (2007), Forecasting the global burden of Alzheimer's disease. Alzheimer's \& Dementia, 3: 186-191. https://doi.org/10.1016/j. jalz.2007.04.381

46. World Health Organisation. Cancer. Erişim Adresi: https://www. who.int/news-room/fact-sheets/detail/cancer (22.02.2021)

47. Bray, F., Ferlay, J., Soerjomataram, I., Siegel, R.L., Torre, L.A. and Jemal, A. (2018), Global cancer statistics 2018: GLOBOCAN estimates of incidence and mortality worldwide for 36 cancers in 185 countries. CA: A Cancer Journal for Clinicians, 68: 394-424. https://doi.org/10.3322/caac.21492

48. Bousquet J, Kiley J, Bateman ED, Viegi G, Cruz AA, Khaltaev N, Ait Khaled N, Baena-Cagnani CE, Barreto ML, Billo N, Canonica GW, Carlsen KH, Chavannes N, Chuchalin A, Drazen J, Fabbri LM, Gerbase MW, Humbert M, Joos G, Masjedi MR, Makino S, Rabe K, To T, Zhi L. Prioritised research agenda for prevention and control of chronic respiratory diseases. Eur Respir J. 2010 Nov;36(5):9951001. doi: 10.1183/09031936.00012610. Epub 2010 Mar 11. PMID: 20223919.
49. Laniado-Laborín R. (2009). Smoking and chronic obstructive pulmonary disease (COPD). Parallel epidemics of the 21 century. International journal of environmental research and public health, 6(1), 209-224. https://doi.org/10.3390/ijerph6010209

50. World Health Organisation. Chronic obstructive pulmonary disease (COPD). Erişim Adresi: https://www.who.int/news-room/ fact-sheets/detail/chronic-obstructive-pulmonary-disease-(copd) (22.02.2021)

51. World Health Organisation. WHO remains firmly committed to the principles set out in the preamble to the Constitution. Erişim Adresi: https://www.who.int/about/who-we-are/constitution (25.02.2021)

52. Wang, P. S., Aguilar-Gaxiola, S., Alonso, J., Angermeyer, M. C., Borges, G., Bromet, E. J., Bruffaerts, R., de Girolamo, G., de Graaf, R., Gureje, O., Haro, J. M., Karam, E. G., Kessler, R. C., Kovess, V., Lane, M. C., Lee, S., Levinson, D., Ono, Y., Petukhova, M., Posada-Villa, J., ... Wells, J. E. (2007). Use of mental health services for anxiety, mood, and substance disorders in 17 countries in the WHO world mental health surveys. Lancet (London, England), 370(9590), 841-850. https://doi.org/10.1016/ S0140-6736(07)61414-7

53. Baxter, A.J., Scott, K.M., Ferrari, A.J., Norman, R.E., Vos, T. and Whiteford, H.A. (2014), Challenging the myth of an "epıdemic" of common mental disorders: trends in the global prevalence of anxiety and depression between 1990 and 2010. Depress Anxiety, 31: 506-516. https://doi.org/10.1002/da.22230

54. The Regional Office for Europe of the World Health Organisation, Mental Health Erişim Adresi: https://www.euro.who.int/_data/ assets/pdf_file/0017/348011/Fact-sheet-SDG-Mental-healthUPDATE-02-05-2018.pdf

55. The Regional Office for Europe of the World Health Organisation, Mental health: Fact sheet. Erişim Adresi: https://www.euro.who. int/_data/assets/pdf_file/0004/404851/MNH_FactSheet_ENG.pdf

56. The Regional Office for Europe of the World Health Organisation, Depression in Europe: facts and figures. Erişim Adresi: https:// www.euro.who.int/en/health-topics/noncommunicable-diseases/ mental-health/news/news/2012/10/depression-in-europe/ depression-in-europe-facts-and-figures (25.02.2021)

57. World Health Organisation, Depression. Erişim Adresi: https:// www.who.int/news-room/fact-sheets/detail/depression (25.02.2021)

58. World Health Organisations. Suicide. Erişim Adresi: https://www. who.int/news-room/fact-sheets/detail/suicide (25.02.2021)

59. World Health Organisation, Depression and Other Common Mental Disorders Global Health Estimates. (2017). Erişim Adresi: https://apps.who.int/iris/bitstream/handle/10665/254610/WHOMSD-MER-2017.2-eng.pdf

60. Jalal H, Buchanich JM, Roberts MS, Balmert LC, Zhang K, Burke DS. Changing dynamics of the drug overdose epidemic in the United States from 1979 through 2016. Science. 2018 Sep 21;361(6408):eaau1184. doi: 10.1126/science.aau1184. PMID: 30237320

61. World Health Organisations, Adolescent and young adult health. Erişim Adresi: https://www.who.int/news-room/fact-sheets/detail/ adolescents-health-risks-and-solutions (25.02.2021)

62. United Nations, World Report On Violence Against Children. (2006). Erişim Adresi: https://resourcecentre.savethechildren.net/ node/2999/pdf/2999.pdf

63. Yuan-Chien Pan, Yu-Chuan Chiu, Yu-Hsuan Lin, Systematic review and meta-analysis of epidemiology of internet addiction, Neuroscience \& Biobehavioral Reviews, Volume 118, 2020, Pages 612-622, ISSN 0149-7634, https://doi.org/10.1016/j. neubiorev.2020.08.013. 
64. de Zwaan, Martina. (2001). Binge eating disorder and obesity. International journal of obesity and related metabolic disorders : Journal of the International Association for the Study of Obesity. 25 Suppl 1. S51-5. 10.1038/sj.ijo.0801699.

65. World Health Organisation. Mental health \& COVID-19. Erişim Adresi: $\quad$ https://www.who.int/teams/mental-health-andsubstance-use/covid-19 (25.02.2021)

66. Bankson H. L. (2009). Health literacy: an exploratory bibliometric analysis, 1997-2007. Journal of the Medical Library Association : JMLA, 97(2), 148-150. https://doi.org/10.3163/15365050.97.2.016

67. Bilir, Nazmi. (2014). Sağıı okur-yazarlığı/Health Literacy. Türkiye Halk Sağlığı Dergisi. 12. 61. 10.20518/thsd.46492.

68. Nancy D. Berkman, Terry C. Davis \& Lauren McCormack (2010) Health Literacy: What Is It?, Journal of Health Communication, 15:sup2, 9-19, DOI: 10.1080/10810730.2010.499985

69. World Health Organisation. Health Promotion. Erişim Adresi: https://www.who.int/healthpromotion/conferences/9gchp/ health-literacy/en/ (19.03.2021)

70. Yılmaz, M , Tiraki, Z . (2016). Sağlık Okuryazarlığı Nedir? Nasıl Ölçülür?. Dokuz Eylül Üniversitesi Hemşirelik Fakültesi Elektronik Dergisi, 9 (4) , 142-147 . Retrieved from https://dergipark.org.tr/ tr/pub/deuhfed/issue/46793/586772

71. Van den Broucke, S. Health literacy: a critical concept for public health. Arch Public Health 72, 10 (2014). https://doi. org/10.1186/2049-3258-72-10

72. World Health Organisations Regional Office For Europe, Health Literacy The Solid Facts. (2013) Erişim Adresi: https://apps.who. int/iris/bitstream/handle/10665/326432/9789289000154-eng. pdf?sequence $=1 \&$ isAllowed $=y$

73. T.C. Sağlık Bakanlığı, Türkiye Sağlık Okuryazarı̆̆ı Düzeyi Ve Ilişkili Faktörleri Araştırması, Editör: Ozkan S,Yazarlar: Ozkan S., Aksakal FBN, Calışkan D., Dikmen AU., ISBN: 978-975-590-6898, 2018.

74. Rufaro Manhanzva, Praise Marara, Theodore Duxbury, Amy Claire Bobbins, Noel Pearse, Erik Hoel, Thandi Mzizi \& Sunitha C. Srinivas (2017) Gender and leadership for health literacy to combat the epidemic rise of noncommunicable diseases, Health Care for Women International, 38:8, 833-847, DOI: 10.1080/07399332.2017.1332062

75. Don Nutbeam, Health literacy as a public health goal: a challenge for contemporary health education and communication strategies into the 21st century, Health Promotion International, Volume 15, Issue 3, September 2000, Pages 259-267, https://doi. org/10.1093/heapro/15.3.259

76. Paakkari, L., \& Okan, O. (2020). COVID-19: health literacy is an underestimated problem. The Lancet. Public health, 5(5), e249e250. https://doi.org/10.1016/S2468-2667(20)30086-4

77. T.C. Sağlık Bakanlığı, COVID-19 Salgın Yönetimi ve Çalışma Rehberi. (1 Ekim 2020) Erişim Adresi: https://covid19.saglik.gov. tr/Eklenti/39265/0/covid-19salginyonetimivecalismarehberipdf. pdf

78. Jorm AF. Mental health literacy: empowering the community to take action for better mental health. Am Psychol. 2012 Apr;67(3):231-43. doi: 10.1037/a0025957. Epub 2011 Oct 31. PMID: 22040221.

79. Van den Broucke, S. Health literacy: a critical concept for public health. Arch Public Health 72, 10 (2014). https://doi. org/10.1186/2049-3258-72-10
80. Diane Levin-Zamir, Orna B. Baron-Epel, Vicki Cohen ve Asher Elhayany (2016) The Association of Health Literacy with Health Behavior, Socioeconomic Indicators and SelfAssessed Health from a National Adult Survey in Israel, Journal of Health Communication, 21: sup2, 61-68, DOI: 10.1080 / 10810730.2016.1207115

81. World Health Organisation, Health Promotion. Erişim Adresi: https://www.who.int/healthpromotion/health-literacy/en/ (11.03.2021)

82. Thomas Abel, David McQueen, Critical health literacy and the COVID-19 crisis, Health Promotion International, Cilt 35, Sayı 6 Aralık 2020, Sayfa 1612-1613, https://doi.org/10.1093/heapro/ daaa040 